\title{
DETERMINANTS OF EMPLOYEE TURNOVER INTENTION
}

\author{
Paweł WÓJCIK \\ Faculty of Economics, Maria Curie Skłodowska University in Lublin; pawel.wojcik@poczta.umcs.lublin.pl, \\ ORCID: 0000-0001-7376-1853
}

Purpose: Voluntary turnover of employees constitutes a challenge for modern organizations, especially when the problem pertains to key specialists or talents. Therefore, the examination of reasons behind such employee decisions is significant.

Design/methodology/approach: The paper discusses conceptual model of employee turnover intention developed on the basis of the review of literature.

Findings: The model consists of three factors determining the turnover intention: job characteristics, work centrality, and organizational commitment.

Research limitations/implications: The model constitutes a theoretical basis for further studies in the issue of turnover intention.

Originality/value: The empirical verification of the model will enable the formulation of recommendations for organizations to limit the turnover intention.

Keywords: turnover intention, work centrality, organizational commitment, job characteristics.

Category of the paper: Conceptual paper.

\section{Introduction}

The issue of voluntary employee turnover presents a considerable challenge for HR departments, especially in the context of the growing shortage of talented employees in modern organizations. The loss of employees translates into a loss for the organization. The profit the employee who resigned would bring to the organization constitutes a direct loss. In addition, the cost of further recruitment, selection, adaptation, training, further turnover, and the loss of motivation ought to be considered as additional costs associated with the issue.

According to the report of MERCER of 2016 (Gutmann, 2016), the overall voluntary employee turnover index amounted to $9.6 \%$. The index amounted to $7.1 \%$ in Europe.

The issue of voluntary employee turnover was first undertaken in the late 1950s (March and Simon, 1958). The interest in the matter grew in the 1990s. Employee turnover remains a current issue. Scholars are still examining factors determining the decision regarding the 
voluntary turnover (Table 1). They indicate that the intention to leave is the strongest predictor of the turnover and occurs when the employee recognizes the opportunity to change the place of employment for a more attractive one. Studies concerning the motivation to leave emphasize the existence of a research gap pertaining to the lack of discussion regarding the issue in terms of organizational perspective - organizationnal factors, and employee perspective - their capital (Lewicka, 2016).

Table 1.

Selected results of studies indicating a relationship among determinants of the turnover intention

\begin{tabular}{|c|c|c|c|c|c|c|c|c|c|c|c|}
\hline & 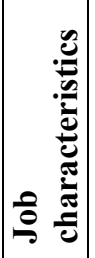 & 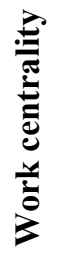 & 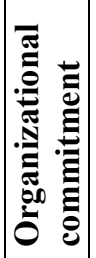 & 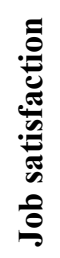 & 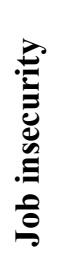 & 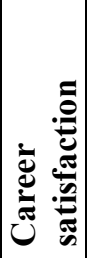 & 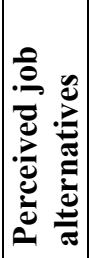 & 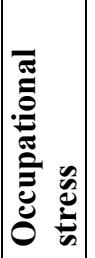 & 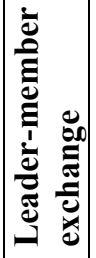 & 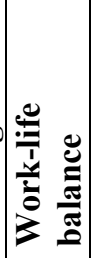 & 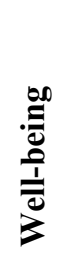 \\
\hline Bal and Kooij, 2011 & & $\mathrm{X}$ & & & & & & & & & \\
\hline Bouckenooghe, Raja and Butt, 2013 & & & & $\mathrm{X}$ & & & & & & & \\
\hline Brawley and Pury, 2016 & & & & $\mathrm{X}$ & & & & & & & \\
\hline Brunetto et al., 2012 & & & $\mathrm{X}$ & & & & & & & & \\
\hline Brunetto et al., 2013 & & & & & & & & & & & $\mathrm{X}$ \\
\hline Fox and Fallon, 2003 & & & & $\mathrm{X}$ & & & & & & $\mathrm{X}$ & \\
\hline Hancock et al., 2013 & & $\mathrm{X}$ & & & & & & & & & \\
\hline Hirschfeld and Field, 2000 & & $\mathrm{X}$ & & & & & & & & & \\
\hline Jiang and Johnson, 2017 & & $\mathrm{X}$ & & & & & & & & & \\
\hline Jiang and Lavaysse, 2018 & & & & & $\mathrm{X}$ & & & & & & \\
\hline Jordan and Troth, 2011 & & & & $\mathrm{X}$ & & & & & $\mathrm{X}$ & & \\
\hline Joseph et al., 2007 & & $\mathrm{X}$ & $\mathrm{X}$ & $\mathrm{X}$ & & $\mathrm{X}$ & $\mathrm{X}$ & & & & \\
\hline Kanungo, 1982 & & $\mathrm{X}$ & & & & & & & & & \\
\hline Khanin, Turel and Mahto, 2012 & & $\mathrm{X}$ & & $\mathrm{X}$ & & & & & & & \\
\hline Krot and Lewicka, 2015 & $\mathrm{X}$ & & & & & & & & & & \\
\hline Lewicka, 2016 & & & $\mathrm{X}$ & & & & & & & & \\
\hline Lu and Gursoy, 2013 & & & & $\mathrm{X}$ & & & & & & & \\
\hline Luna-Arocas and Camps, 2008 & & & $\mathrm{X}$ & & & & & & & & \\
\hline Maertz et al., 2007 & $\mathrm{X}$ & & & & & & & & & & \\
\hline Mahdi et al., 2012 & & & & $\mathrm{X}$ & & & & & & & \\
\hline Mannheim, Baruch and Tal, 1997 & & $\mathrm{X}$ & & & & & & & & & \\
\hline Markey, Ravenswood and Webber, 2012 & $\mathrm{X}$ & & & & & & & & & & \\
\hline Martin, 2007 & & & $\mathrm{X}$ & $\mathrm{X}$ & & & & & & & \\
\hline Martin and Roodt, 2008 & & & $\mathrm{X}$ & $\mathrm{X}$ & & & & & & & \\
\hline Oosthuizen, Coetzee and Munro, 2016 & & & & $\mathrm{X}$ & & & & & & $\mathrm{X}$ & \\
\hline Park and Shaw, 2013 & & $\mathrm{X}$ & & & & & & & & & \\
\hline Park et al., 2017 & & $\mathrm{X}$ & & $\mathrm{X}$ & & & & $\mathrm{X}$ & & & \\
\hline Schmidt and Lee, 2008 & & $\mathrm{X}$ & $\mathrm{X}$ & & & & & & & & \\
\hline Shalley, Gilson and Blum, 2000 & $\mathrm{X}$ & & & & & & & & & & \\
\hline Singh and Loncar, 2010 & & & & $\mathrm{X}$ & & & & & & & \\
\hline Snir and Harpaz, 2002 & & $\mathrm{X}$ & & & & & & & & & \\
\hline Tett and Meyer, 1993 & & & $\mathrm{X}$ & $\mathrm{X}$ & & & & & & & \\
\hline Vandenberghe et al., 2007 & & & $\mathrm{X}$ & & & & & & & & \\
\hline Wnuk, 2018 & & & $\mathrm{X}$ & & & & & & & & \\
\hline Wright and Bonett, 2007 & & & & $\mathrm{X}$ & & & & & & & $\mathrm{X}$ \\
\hline
\end{tabular}

Source: own study. 
On the basis of the synthesis of literature, it can be observed that researchers examining the turnover intention differ in their conclusions regarding variables determining the phenomenon. However, the most frequently recurring features include: job characteristics, work centrality, organizational commitment and job satisfaction. A decision was made to disregard job satisfaction and include job characteristics in the paper instead. When verifying the model, employees evaluate individual job characteristics to establish if these are satisfactory and motivating for them. The establishment of specific job characteristics will have a greater practical significance for the development of organizational actions aiming to limit the turnover intention.

\subsection{Turnover intention}

The literature of the subject offers a relatively straightforward definition of the turnover intention. The most popular definition was offered by Tett and Meyer (1993, p. 262). They stated that it is "a conscious and deliberate willfulness to leave the organization". Similarly, Schyns, Torka and Gössling (2007, p. 660) define the turnover intention as "an employee's intention to voluntarily change jobs or companies". Two issues are worth mentioning at this point. First of all, the source of the intention can be traced back to the employee and not to the organization's actions. Secondly, the intention refers to the internal state of an individual and not their immediate actions. The turnover intention may be high or low depending whether the employee is interested in resigning.

According to Bakker, Demerouti and Verbeke (2004), Janse Van Rensburg (2004), Kanungo (1982) and Roodt (2004), the turnover intention is a kind of withdrawal resulting from the lack of identification with the workplace (Bothma and Roodt, 2012). The intention is an adequate predictor of subsequent employee behaviour. It constitutes a multi-faceted process encompassing attitudes, decision-making and behaviour (Martin, 2007).

Several authors, e.g. Mobley (1982), Sager, Griffeth and Hom (1998), Jacobs and Roodt (2007) and Bester (2012), believe that the intention constitutes the final stage preceding a person's decision concerning the resignation.

The research gap pertaining to the studies concerning the relationship between organizational factors and the turnover intention was indicated by Lewicka (2016) and Hauk (2014).

\subsection{Job characteristics}

According to Hauk (2014), the establishment of specific job characteristics which exert an impact upon employee satisfaction and motivation is significant for the development of adequate work environment. On the basis of studies and analyses, Hauk isolated 11 fundamental job characteristics: job complexity, physical requirements and working conditions, job feedback, autonomy, ergonomics, feedback from others, equipment and facilities, 
interrelations among employees, interactions with the organization, social support - friendships in the organization, and work significance.

According to Krzyszkowska (2015), reasons for leaving the organization are usually associated with the workplace and stem from dissatisfaction with working conditions. Spector and Jex (1991) indicated a vital significance of autonomy, duties, feedback and the scope of work for the turnover intention.

Markey, Ravenswood and Webber (2012) studied the impact of the quality of job characteristics upon the turnover intention. They discovered that employees manifest a lower intention if they perceive their work environment as positive, i.e. one characterized by low stress level, where managers appreciate their subordinates, and employees do not feel threatened. On the other hand, studies by Shalley, Gilson and Blum (2000) indicated the existence of a relationship between work environment characterized by creativity and complexity and the turnover intention. Studies by Krot and Lewicka (2015) proved the existence of a relationship between organizational justice and the turnover invention.

\subsection{Work centrality}

Work centrality constitutes a further variable determining the turnover intention. Much like regarding the turnover intention, scholars are relatively unanimous in defining the concept. According to Diefendorff et al. (2002), it pertains to a personal perception of work as a chief element of one's life. In addition, Walsh and Gordon (2008) define work centrality as a personal belief of an individual regarding the position work occupies in their lives. It is noteworthy that individuals' perception of work significance does not pertain to specific organizations they are employed in, but to work in general (Jiang and Johnson, 2017). The significance of work

emerges from life and work experiences. It exerts a negative impact upon the intention concerning retirement but not upon the change of employment (Schmidt and Lee, 2008).

The relationship between work centrality and the turnover intention was indicated by Kanungo (1982). The relationship was confirmed by e.g. Mannheim, Baruch and Tal (1997), Schmidt and Lee (2008), Bal and Kooij (2011), Snir and Harpaz (2002), Hirschfeld and Field (2000) and Jiang and Johnson (2017).

\subsection{Organizational commitment}

Organizational commitment constitutes the final determinant of the turnover intention. Based upon the review of literature, it may be argued that the commitment is one of the most widely studied phenomena influencing the turnover intention.

The concept of organizational commitment was developed by Meyer and Allen (1991). It was based upon the psychological bond between the employee and organization. It is composed of three elements: affective commitment, continuance commitment and normative commitment (Mendryk and Rakowska, 2017). 
Studies indicate that all the components are connected with the turnover intention. The relationship was confirmed by e.g. Meyer et al. (2002), Vandenberghe et al. (2007), Luna-Arocas and Camps (2008) and Schmidt and Lee (2008). In addition, Lewicka (2016) and Wnuk (2018) also studied the field.

It turned out that affective commitment has a greater significance with regard the turnover intention. Strong affective commitment denotes that employees remain in the organization out of their choice (Meyer et al., 2002; Vandenberghe et al., 2007).

\section{Conceptual framework}

The research model was developed on the basis of the review of literature (Fig. 1). The following five hypotheses describe the relations between individual variables:

$\mathrm{H1}$ : There exists a relationship between job characteristics and the turnover intention.

$\mathrm{H} 2$ : There exists a relationship between organizational commitment and the turnover intention.

H3: There exists a relationship between work centrality and the turnover intention.

H4: There exists a relationship between organizational commitment and job characteristics.

H5: There exists a relationship between organizational commitment and work centrality.

The first three hypotheses pertain to direct relations emerging between the determinant and the turnover intention. Hypothesis 4 and 5 make a premise of existence of a relationship between organizational commitment, job characteristics and work centrality.

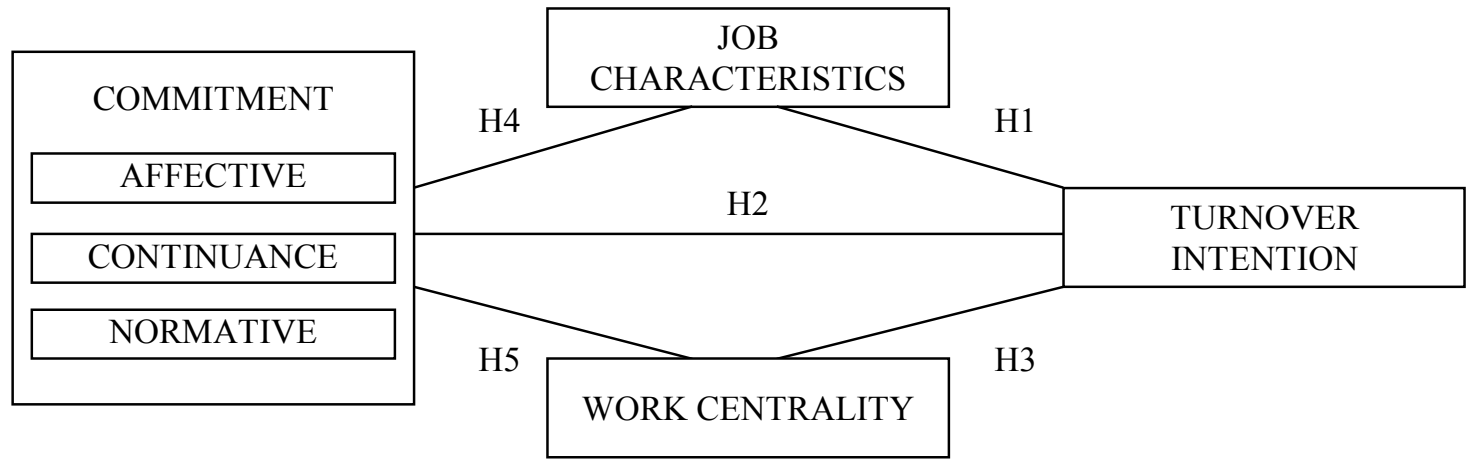

Figure 1. Model of factors determining the turnover intention. Source: own study.

In the model, it can be observed that there are three sources of determinants of the turnover intention. Job characteristics are an element directly determined by the organization. Work centrality finds its source in the employee. It determines the role of work in a person's life. It is not attributed to a specific organization. Therefore, the organization has no influence over it. On the one hand, organizational commitment is related to job characteristics, and to work centrality on the other. 


\section{Limitation and Further Research}

The present concept of the research model concerning the turnover intention is theoretical in its nature at the moment. Further empirical studies are required to verify the model. The model incorporated determinants of the turnover intention which, according to studies, exert the strongest impact upon the intention. This means that the model does not include all determinants. When verified empirically, the model will have significance for human resources management. It will enable recommendations for organizations pursuing to limit the turnover intention to be formulated. The research model presented in the paper will be applied in the doctoral dissertation of Paweł Wójcik. The dissertation is titled "Determinants of the turnover intention of employees in IT sector". The dissertation is supervised by Anna Rakowska, Associate Professor at Maria Curie Skłodowska University in Lublin.

\section{References}

1. Bakker, A.B., Demerouti, E., and Verbeke, W. (2004). Using the job demands-resources model to predict burnout and performance. Human Resource Management, 43(1), pp. 83104. doi: 10.1002/hrm.20004.

2. Bal, P.M., and Kooij, D. (2011). The relations between work centrality, psychological contracts, and job attitudes: The influence of age. European Journal of Work and Organizational Psychology, 20(4), pp. 497-523. doi: 10.1080/13594321003669079.

3. Bester, F. (2012). A model of work identity in multicultural work settings (Unpublished DPhil thesis). Johannesburg: University of Johannesburg.

4. Bothma, C.F.C., and Roodt, G. (2012). Work-based identity and work engagement as potential antecedents of task performance and turnover intention: Unravelling a complex relationship. SA Journal of Industrial Psychology, 38(1), pp. 1-17. doi: 10.4102/ sajip.v38i1.893.

5. Bouckenooghe, D., Raja, U., and Butt, A.N. (2013). Combined effects of positive and negative affectivity and job satisfaction on job performance and turnover intentions. Journal of Psychology, 147(2), pp. 105-123. doi: 10.1080/00223980.2012.678411.

6. Brawley, A.M., and Pury, C.L. (2016). Work experiences on MTurk: Job satisfaction, turnover, and information sharing. Computers in Human Behavior, 54, pp. 531-546. doi: 10.1016/j.chb.2015.08.031.

7. Brunetto, Y., Teo, S.T., Shacklock, K., and Farr-Wharton, R. (2012). Emotional intelligence, job satisfaction, well-being and engagement: Explaining organizational 
commitment and turnover intentions in policing. Human Resource Management Journal, 22, pp. 428-441. doi: 10.1111/j.1748-8583.2012.00198.x.

8. Brunetto, Y., Xerri, M., Shriberg, A., Farr-Wharton, R., Shacklock, K., Newman, S., and Dienger, J. (2013). The impact of workplace relationships on engagement, well-being, commitment and turnover for nurses in Austrailia and the USA. Journal of Advanced Nursing, 69, pp. 2786-2799. doi: 10.1111/jan.12165.

9. Diefendorff, J.M., Brown D.J., Kamin A.M., and Lord R.G. (2002). Examining the Roles of Job Involvement and Work Centrality in Predicting Organizational Citizenship Behaviors and Job Performance. Journal of Organizational Behavior, 23(1), pp. 93-108. doi: 10.1002/job.123.

10. Fox, S.R., and Fallon, B.J. (2003). Modeling the effect of work/life balance on job satisfaction and turnover intentions, Symposium paper presented at the 5th Australian Industrial and Organisational Psychology Conference, Melbourne, Australia.

11. Gutmann, P. (2016). Tackling Trends in Turnover. Frankfurt, Germany: Mercer Webcast Series.

12. Hancock, J.I., Allen, D.G., Bosco, F.A., McDaniel, K.R., and Pierce, C.A. (2013). Meta-analytic review of employee turnover as a predictor of firm performance. Journal of Management, 39, pp. 573-603. doi: 10.1177/0149206311424943.

13. Hauk, M. (2014). Kwestionariusz Cech Pracy - opracowanie polskiej wersji narzędzia do badania cech pracy i środowiska zawodowego: wstępne wyniki badań. Acta Universitatis Lodziensis. Folia Psychologica, 18, pp. 129-153.

14. Hirschfeld, R.R., and Field, H.S. (2000). Work centrality and work alienation: distinct aspects of a general commitment to work. Journal of Organizational Behavior, 21, pp. 789800. doi: 10.1002/1099-1379(200011)21:7<789::AID-JOB59>3.0.CO;2-W.

15. Jacobs, E., and Roodt, G. (2007). The development of a knowledge sharing construct to predict turnover intentions. Aslib Proceedings, 59(3), pp. 229-248. doi: 10.1108/ 00012530710752034.

16. Janse van Rensburg, K. (2004). A predictive model of employee commitment in an organisation striving to become world-class (Unpublished Doctoral thesis). Johannesburg, South Africa: Rand Afrikaans University.

17. Jiang, L., and Johnson, M.J. (2017). Meaningful Work and Affective Commitment: A Moderated Mediation Model of Positive Work Reflection and Work Centrality. Journal of Business and Psychology, 33(4), pp. 545-558. doi: 10.1007/s10869-017-9509-6.

18. Jiang, L., and Lavaysse, L.M. (2018). Cognitive and Affective Job Insecurity: A Meta-Analysis and a Primary Study. Journal of Management, 44(6), pp. 2307-2342. doi: $10.1177 / 0149206318773853$.

19. Jordan, P.J., and Troth, A.C. (2011). Emotional intelligence and leader member exchange: The relationship with employee turnover intentions and job satisfaction. Leadership \& 
Organization Development Journal, 32(3), pp. 260-280. doi: 10.1108/ 01437731111123915.

20. Joseph, D., Ng, K.-Y., Koh, Ch., and Angs, S. (2007). Turnover of Information Technology Professionals: A Narrative Review, Meta-Analytic Structural Equation Modeling, and Model Development. MIS Quarterly, 31(3), pp. 547-577. doi: 10.2307/25148807.

21. Kanungo, R.N. (1982). Work alienation: An integrative approach. New York: Praeger.

22. Khanin, D., Turel, O., and Mahto, R.V. (2012). How to Increase Job Satisfaction and Reduce Turnover Intentions in the Family Firm: The Family-Business Embeddedness Perspective. Family Business Review, 25(4), pp. 391-408. doi: 10.1177/ 0894486512441944.

23. Krot, K., and Lewicka, D. (2015). Wpływ jakości środowiska pracy na zachowania pracowników. Zeszyty Naukowe Uniwersytetu Szczecińskiego. Studia i Prace Wydziału Nauk Ekonomicznych i Zarządzania. Zarzadzanie, 39(4), pp. 95-109.

24. Krzyszkowska, P. (2015). Zwolnienia pracowników jako nieuchronny proces zachodzący w działalności każdej organizacji. Zeszyty Naukowe Politechniki Ślaskiej, seria Organizacja i Zarzadzanie, 82(1940), pp. 101-110.

25. Lewicka, D. (2016). Jak zatrzymać wartościowych pracowników w organizacji? Wyzwania dla strategicznego ZKL (zarządzania kapitałem ludzkim). Prace Naukowe Uniwersytetu Ekonomicznego we Wrocławiu. Zarzadzanie strategiczne w teorii i praktyce, 444, pp. 274284. doi: $10.15611 / \mathrm{pn} .2016 .444 .25$.

26. Lu, A., and Gursoy, D. (2013). Impact of job burnout on satisfaction and turnover intention: Do generational differences matter? Journal of Hospitality \& Tourism Research, 40(2), pp. 210 - 235. doi: 10.1177/1096348013495696.

27. Luna-Arocas, R., and Camps, J. (2008). A model of high performance work practices and turnover intentions. Personnel Review, 37(1), pp. 26-46. doi: 10.1108/ 00483480810839950.

28. Maertz, C.P., Griffeth, R.W., Campbell, N.S., and Allen, D.G., (2007). The effects of perceived organizational support and perceived supervisor support on employee turnover. Journal of Organizational Behaviour, 28, pp. 1059-1075. doi: 10.1002/job.472.

29. Mahdi, A.F., Zin, M.Z.M., Nor, M.R.M., Sakat, A.A., and Naim, A.S.A. (2012). The relationship between job satisfaction and turnover intention. American Journal of Applied Sciences, 9(9), pp. 1518-1526.

30. Mannheim, B., Baruch, Y., and Tal, J. (1997). Alternative Models for Antecedents and Outcomes of Work Centrality and Job Satisfaction of High-Tech Personnel. Human Relations, 50(12), pp. 1537-1562. doi: 10.1177/001872679705001204.

31. March, J.G., and Simon, H.A. (1958). Organizations. Oxford, England.

32. Markey, R., Ravenswood, K., and Webber, D.J. (2012). The impact of the quality of the work environment on employees' intention to quit. Economics Working Paper Series, 1220, pp. 1-33. 
33. Martin, A. (2007). Employee Perceptions of Organisational Commitment, Job Satisfaction and Turnover Intentions in a Post-merger Institution (Master's dissertation). Johannesburg: University of Johannesburg, Faculty of Management.

34. Martin, A., and Roodt, G. (2008). Perceptions of organisational commitment, job satisfaction and turnover intentions in a post-merger South African tertiary institution. SA Journal of Industrial Psychology, 34(1), pp. 23-31. doi: 10.4102/sajip.v34i1.415.

35. Mendryk, I., and Rakowska, A. (2017). Poczucie sprawiedliwości organizacyjnej a poziom zaangażowania pracowników. Wyniki badań. Annales Universitatis Mariae CurieSkłodowska Lublin - Polania, Sectio H, 51(4), pp. 237-246. doi: 10.17951/h.2017.51.4.237.

36. Meyer, J.P., and Allen, N.J. (1991). A three-component conceptualization of organizational commitment. Human Resource Management Review, 1(1), pp. 61-89. doi: 10.1016/10534822(91)90011-Z.

37. Meyer, J.P., Stanley, D.J., Herscovitch, L., and Topolnytsky, L. (2002). Affective, continuance, and normative commitment t10.17951/h.2017.51.4.237o the organization: a meta-analysis of antecedents, correlates, and consequences. Journal of Vocational Behavior, 61(1), pp. 20-52. doi: 10.1006/jvbe.2001.1842.

38. Mobley, W.H. (1982). Some unanswered questions in turnover and withdrawal research. Academy of Management Review, 7(1), pp. 111-116. doi: 10.5465/amr.1982.4285493.

39. Oosthuizen, R.M., Coetzee, M., and Munro, Z. (2016). Work-life balance, job satisfaction and turnover intention amongst information technology employees. Southern African Business Review, 20(1), pp. 446-467. doi: 10.25159/1998-8125/6059.

40. Park, J., Yoon, S., Moon, S.S., Lee, K.H., and Park, J. (2017). The Effects of Occupational Stress, Work-Centrality, Self-Efficacy, and Job Satisfaction on Intent to Quit Among LongTerm Care Workers in Korea. Home Health Care Services Quarterly, 36(2), pp. 96-111. doi: 10.1080/01621424.2017.1333479.

41. Park, T., and Shaw, J. D. (2013). Turnover rates and organizational performance: A metaanalysis. Journal of Applied Psychology, 98, pp. 268-309. doi: 10.1037/a0030723.

42. Roodt, G. (2004). Turnover Intentions (Unpublished manuscript). Johannesburg, South Africa: University of Johannesburg.

43. Sager, J.K., Griffeth, R.W., and Hom, P.W. (1998). A comparison of structural models representing turnover cognitions. Journal of Vocational Behavior, 53(2), pp. 254-273. doi: 10.1006/jvbe.1997.1617.

44. Schmidt, J.A., and Lee, K. (2008). Voluntary Retirement and Organizational Turnover Intentions: The Differential Associations with Work and Non-Work Commitment Constructs. Journal of Business and Psychology, 22(4), pp. 297-309. doi: 10.1007/ s10869-008-9068-y.

45. Schyns, B., Torka, N., and Gössling, T. (2007). Turnover intention and preparedness for change: Exploring leader-member exchange and occupational self-efficacy as antecedents 
of two employability predictors. Career Development International, 12(7), pp. 660-679. doi: 10.1108/13620430710834413.

46. Shalley, C.E., Gilson, L.L., and Blum, T.C. (2000). Matching creativity requirements and the work environment: Effects on satisfaction and intentions to leave. Academy of Management Journal, 43, pp. 215-223. doi: 10.2307/1556378.

47. Singh, P. and Loncar, N. (2010). Pay satisfaction, job satisfaction and turnover intent. Relations Industrielles/Industrial Relations, 65(3), pp. 470-490. doi: 10.7202/044892ar.

48. Snir, R., and Harpaz, I. (2002). Work-leisure relations: leisure-orientation and the meaning of work. Journal of Leisure Research, 34(2), pp. 178-203. doi: 10.1080/ 00222216.2002.11949968.

49. Spector, P.E., and Jex, S.M. (1991). Relations of job characteristics from multiple data sources with employee affect, absence, turnover intentions, and health. Journal of Applied Psychology, 76(1), pp. 46-53. doi: 10.1037/0021-9010.76.1.46.

50. Tett, R.P., and Meyer, J.P. (1993). Job satisfaction, organisational commitment, turnover intention and turnover: Path analysis based on meta-analytic findings. Personnel Psychology, 46(2), pp. 259-293. doi: 10.1111/j.1744-6570.1993.tb00874.x.

51. Vandenberghe C., Bentein K., Michon R., Chebat J., Tremblay M., and Fils J. (2007). An examination of the role of perceived support and employee commitment in employeecustomer encounters. Journal of Applied Psychology, 92(4), pp. 1177-1187. doi: 10.1037/ 0021-9010.92.4.1177.

52. Walsh, K., and Gordon, J. R. (2008). Creating an individual work identity. Human Resource Management Review, 18(1), pp. 46-61. doi: 10.1016/j.hrmr.2007.09.001.

53. Wnuk, M. (2018). Psychospołeczne uwarunkowania dobrostanu pracowników i zamiaru odejścia z organizacji. Weryfikacja modelu. Czasopismo Psychologiczne - Psychological Journal, 24(2), pp. 361-371. doi: 10.14691/CPPJ.24.2.361.

54. Wright, T.A., and Bonett, D.G. (2007). Job satisfaction and psychological well-being as nonadditive predictors of workplace turnover. Journal of Management, 33(2), pp. 141-160. doi: $10.1177 / 0149206306297582$. 